Volume 10 No. 2 September 2019

P-ISSN 2086-6178 E-ISSN 2579-3292

http://ejournal.bsi.ac.id/ejurnal/index.php/jkom

\title{
Nilai Estetika Pada Film Layar Lebar Indonesia The Raid
}

\author{
Muhammad Ichsan \\ Universitas Bina Sarana Informatika \\ e-mail: muhammad.mch@bsi.ac.id
}

Cara Sitasi: Ichsan Muhammad. Nilai Estetika Pada Film Layar Lebar Indonesia The Raid. Jurnal Komunikasi, 10(2), 119-131.

\begin{abstract}
Everything that is phenomenal becomes basic for human filmmakers to become a commercial work. The Raid, this big-screen movie really puts forward the beauty of visuals which indeed has a special attraction among Indonesian movie lovers. The Raid is an action-packed film where challenging scenes color the contents of the film. The aesthetic meaning in the film The Raid is very much influenced by the progress of cinematographic technology and also the workers behind the scenes of the film. The shooting techniques that were carried out were very very high quality so that they were different from previous Indonesian action films such as the Martyrs, Merantau and many more. Packaged with modern cinema techniques as well as action scenes with totality with quality actors. The author wants to know the visual aesthetic values contained in the film The Raid especially through verbal and nonverbal communication in interpreting the visual aesthetics of the film The Raid. The key to this research is that the picture message (visual) captured by the audience can give meaning to the beauty of the image on a big screen Indonesian film.
\end{abstract}

Keywords: aesthetics, value, film

\section{PENDAHULUAN}

Film merupakan transformasi dari gambaran-gambaran kehidupan manusia. Kehidupan manusia penuh dengan simbol yang mempunyai makna dan arti berbeda, dan lewat simbol tersebut film memberikan makna yang lain lewat bahasa visualnya. Film juga merupakan sarana ekspresi indrawi yang khas dan efisien, aksi dan karateristik yang dikomunikasikan dengan kemahiran mengekspresikan image yang ditampilkan dalam film yang kemudian menghasilkan makna tertentu yang sesuai konteksnya.

Segala sesuatu yang fenomenal menjadi basic bagi insan perfilman untuk dijadikan suatu karya yang komersil. The Raid, film layar lebar ini amat sangat mengedepankan keindahan visual yang memang mempunyai daya tarik tersendiri dikalangan penikmat film Indonesia. The Raid adalah film bergenre action dimana adegan-adegan yang penuh tantangan mewarnai isi film tersebut.Sementara jika dilihat dari segi cerita termasuk kedalam kategori mudah dicerna tanpa harus membutuhkan daya nalar yang ekstra seperti jika menyaksikan film-film bergenre lika
liku.Apakah mayoritas masyarakat Indonesia memang hanya menyukai film yang rendah penalaran dan mengedepankan gambar visual yang bagus sekarang ini. Hal ini dapat dilihat dari ketertarikan penonton pada saat penayangan perdana film tersebut.Apakah ini merupakan sebuah awal dari kembalinya kejayaan dunia perfilman Indonesia seperti beberapa dekade silam atau hanya sekelebat sebagai hiburan semata saja.

Jika dilihat lebih dalam lagi kedua film ini merupakan produk dari para pekerja belakang layar mancangara bukan pribumi.Hal ini berkaitan dengan segmentasi penonton Indonesia terhadap lingkungan tempat tinggal,status ekonomi sosial terhadap tayangan yang digemari.Karena tidak semua masyarakat menyukai tayangan yang sama dikarenakan tingkat pendidikan dan lingkungan yang mempengaruhi.Masyarakat yang berstatus ekonomi menengah kebawah biasanya lebih menyukai tayangan yang tidak melibatkan otak untuk berfikir karena sudah lelah seharian bekerja.Tapi karya seni tidak selalu "indah" seperti pada persoalan dalam estetika,maka diperlukan suatu biadang khusus yang benarbenar menjawab tentang apa hakekat seni atau 
arts itu.Lahirlah yang dinamakan "filsafat seni",jadi perbedaan antara estetika dan filsafat seni hanya objek materialnya saja.Estetika mempersoalkan hakekat keindahan alam dan karya seni,sedangkan filsafat seni mempersoalkan hanya karya seni atau benda yang disebut seni (Sumardjo, 2000)

Makna estetika dalam film The Raid amat sangat dipengaruhi dari sisi kemajuan teknologi sinematografi dan juga para pekerja dibelakang layar film tersebut.Tekhnik-tekhnik pengambilan gambar yang dilakukan pun amat sangat bermutu sehingga berbeda dengan filmfilm action Indonesia terdahulu seperti Sang Martir,Merantau dan masih banyak lagi.Dilihat dari apa yang telah dijabarkan diatas penulis ingin meneliti masalah tersebut khususnya mengenai ketertarikan masyarakat tentang visual yang modern dalam film action Indonesia belakangan ini yaitu The Raid.

Oleh karena itulah, penulis sangatlah tertarik untuk mengangkat masalah ini sebagai bahan pembuatan penulisan ilmiah karena penulis ingin mengetahui nilai-nilai estetika visual yang terkandung dalam film The Raid khususnya melalui komunikasi verbal dan nonverbal dalam memaknai estetika visual dari film The Raid. Kunci dari penelitian ini adalah pesan gambar (visual) yang ditangkap oleh penonton dapat memberikan makna keindahan gambar pada sebuah film layar lebar Indonesia.

Film

Menurut Kamus Besar Bahasa Indonesia, film dapat diartikan dalam dua pengertian. Yang pertama, film merupakan sebuah selaput tipis berbahan seluloid yang digunakan untuk menyimpan gambar negatif dari sebuah objek. Yang kedua, film diartikan sebagai lakon atau gambar hiduap. Dalam konteks khusus, film diartikan sebagai lakon hidup atau gambar gerak yang biasanya juga disimpan dalam media seluloid tipis dalam bentuk gambar negatif. Meskipun kini film bukan hanya dapat disimpan dalam media selaput seluloid saja. Film dapat juga disimpan dan diputar kembali dalam media digital.

Di dalam Anggaran Dasar Pasal 3 pada

Persatuan Karyawan Film dan Televisi Indonesia yang merupakan Keputusan Kongres ke-8 pada 1995 menyatakan bahwa:

"Film dan televisi adalah karya cipta seni dan budaya yang merupakan media komunikasi massa pandang-dengar yang dibuat berdasarkan asas sinematografi dengan direkam pada pita seluloid, pita video, piringan video, dan atau bahan hasil teknologi lainnya dalam bentuk, jenis, ukuran, melalui kimiawi, proses elektronik, atau proses lainnya".

Film juga merupakan serangkaian gambar-gambar yang diambil dariobyek yang bergerak memperlihatkan suatu serial peristiwaperistiwagerakan yang berlaku secara berkesinambungan, yang berfungsi sebagaimedia hiburan, pendidikan, dan penerangan. Sebagai salah satu mediainformasi maka film secara otomatis akan membawa dampak (side effect) baik itu positif maupun negatif kepada penontonnya.

Menurut Dr. Phil Astrid Susanto, film adalah :

Gambar yang bergerak dikenal dengan gambar hidup dan memang gerakan itumerupakan unsur pemberi hidup kepada suatu gambar, namun betapapunsempurnanya dan modernnya teknik yang dipergunakan belum mendekatikenyataan hidup sehari-hari sebagaimana film. Untuk meningkatkan kesandan dampak dari film, suatu film diiringi suara yang dapat berupa dialogobyek itu memperlihatkan suatu serial gerakan atau momen yangberlangsung secara terus-menerus, kemudian diproyeksikan ke dalamsebuah layer dengan memutarnya dalam kecepatan tertentu sehinggamenghasilkan sebuah gambar hidup. (Susanto, 1982)

Dari penjelasan di atas dapat disimpulkan bahwa film padadasarnya merupakan serangkaian gambar yang diambil dari obyek bergerak, yang kemudian menghasilkan serial peristiwa-peristiwa secarakontinyu dan berfungsi sebagai media komunikasi, media hiburan,pendidikan dan penerangan serta diiringi dengan unsur ekspresi penguatseperti musik, dialog dan juga warna sehingga mampu membuat film itumenjadi serealistis mungkin. Tema cerita dalam film biasa berangkat dari fenomena sosial yang terjadi di tengah masyarakat.

\section{Gestur dan Komunikasi}

Karena kata ekspresi berarti "mendorong keluar" maka sudah menjadi sifat alamiah manusia untuk mengeksternalkan perasaan atau ideanya, mendorong keluar.Aktifitasnya ekspresi adalah bagian dari 
pikiran dan perasaan kita. Proses eksternalisasi ini terus berlanjut bahkan ketika kita sedang sendiri

Implus, perasaan atau reaksi yang kita miliki menimbulkan energi dari dalam diri yang selanjutnya mengalir keluar, mencapai dunia luar dalam bentuk yang bermacam macam : kata-kata, bunyi, gerak, postur dan infleksi (perubahan nada suara). Umumnya, setiap tanda eksternal dari perasaan dan pikiran dan pikiran dapat disebut gestur. Dibagian ini kita akan membaginya secra sistematis dalam dua tipe yaitu fisik dan vokal, yang berhubungan dengan gestur yang dapat dilihat dan yang dapat didengar. Gestur vokal dibagi lagi menjadi verbal (mengucapkan kata-kata) dan nonverbal (bunyi-bunyi yang kita gunakan, termasuk inlfkesi dan penekaan yang penakanan yang mempengaruhi arti emosional dari kata-kata yang kita ucapkan). Karena penulis naskah akan memberikan gestur gestur verbal dalam bentuk kata-kata di naskah, tugas si aktor adalah menyelidiki aspek-aspek nonverbal dari gestur karakter yang dimainkannya, gestur-gestur fisik, postur, infleksi dan sebagainya. (Sitorus, 2002; 91)

Walaupun masyarakat berbeda-beda, banyak tipe gestur yang sama yang dipergunakan untuk meningkatkan atau menggantikan komunikasi verbal. Ada gestur gestur yang memberikan arti konsisten dalam situasi-situasi yang serupa. Dengan demikian berfungsi sebagai satu sistem simbolis, yang istilahnya lebih dikenal dengan nama bahasa tubuh. Karena fungsi aimbolis ini, gestur memberikan analogi yang terbentuk fisik unutk aksi-aksi atau perasaan-perasaan yang sedang diekspresikan atau digambarkan.Ketika bahasa verbal memberikan sistem komunikasi yang artinya sudah cukup jelas dan tepat, bahasa tubuh memberikan informasi tentang perasaanperasaan dan aksi-aksi dengan lebih ekspresif daripada kata-kata. Dalam buku Literature as Experince dikatakan :

Gestur mencapai nilai analogis tertinggi ketika mengekspresikan emosi, tetapi gestur terus berfungsi sebagai pernyataan-pernyataan ditempat umum, di permainan-permainan dan bahkan dalam percintaan.Segi komunikatif yang diciptakan gestur dapat beragam dari yang paling universal sampai yang paling aneh, bahkan bodoh.Gestur dapat menggantikan kata-kata atau mendukung kata-kata.

\section{Fungsi Gestur}

Bahasa gestur dapat dibagi menjadi 4 kategori umu yaitu :

1. Ilustrasi atau imitatif

2. Indikatif

3. Empatik

4. Autistik

Gestur yang sifatnya ilustrasi adalah gestur yang disebut "pantonmimik" ketika mencoba mengkomunikasinya informasi spesifik ("kontak itu besarnya setinggi ini dan selebar ini").Gestur indikatif dipakai untuk menunjuk ("disebelah"). Gestur empatik memberikan informasi yang subjektif daripada objektif, berhubungan dengan bagaimana orang merasakan sesuatu (ketika kita mengarahkan:"sekarang, dengar aku!" sambil meninju kepalan tangan kita ke atas meja atau menunjuk jari kita ke muka musuh). Gestur autistik (arti harafiahnya "kepada diri") tidak dimaksud untuk komunikasi dengan diri sendiri. Misalnya, ketika seseorang yang sedang mendengar orang lain berbicara memiliki perasaan benci kepada lawan bicaranya tetapi harus menutupinya, maka dia akan melipat tangan dengan rapat sekali dengan telapak masuk di sela sela kedua ketiak di depan anda. Dengan tingkah laku rahasia ini.Orang itu menyatakan aksi simbolis, merasa puas ketika sedang mecekik lawan bicaranya.Daging dianatara puas ketika mencekik lawan bicaranya itu.walaupungestur seperti itu sering tersembunyi, secara tidak sadar, sering kali orang disekitar kita dapat mengenali dan merasakannya.Tentu saja realitanya keempat kategori ini tidak nyata terpisah tetapi sengaja dipisah untuk memudahkan pelajaran kita tentang gestur dan hampir smua gestur yang kita pakai kombinasi dari dua atau tiga kategori diatas. (Sitorus, 2002)

\section{Aktor dan Suaranya}

Budaya kita lebih menekankan katakata sebagai satu cara untuk menyampaikan informasi dan kadang-kadang hal tersebut membuat kita lupa bahwa suara, selain dari mengucapkan kata-kata, adalah bagian utama dari mekanisme ekspresi. Sementara kemapuan kita mengartikulasi kata-kata adalah kemampuan yang dipelajari, ekspresi suara adalah sikap naluri, bahkan sudah di mulai sejak kita berumur 2 bulan.Dengan demikian, proses berbicara itu mungkin saja terhadap 
komunikasi yang formal daripada bunyi-bunyi alamiah yang dikeluarakan oleh suara.Aktor sering didikte oleh kata-kata sehingga ragu-ragu atau tidak mampu membumbui pengucapan dialognya dengan bahkan sedikitpun bunyi nonverbal yang dipergunakan dalam kehidupan sehari sehari.Sangat disayangkan, karena bunyi suara adalah salah satu tipe gestur penting, yang paling dalam mengekspresikan kepribadian dan sangat universal pengungkapannya. Margaret Schlauch, dalam bukunya The Gift of Language mengatakan :

Kita menggunkan cara-cara yang nonlinguistik ini untuk mengekspresikan ideide, sebagai pendukung berbicara.Tangisan infleksi nada, gestur adalah cara-cara berkomunikasi yang lebih universal untuk disampaikan ke binatang. (Sitorus, 2002)

\section{Komunikasi Verbal dan Non Verbal}

Komunikasi verbal dan non verbal merupakan dua bentuk dari tindak komunikasi(communication act) yang tidak dapat dipisahkan.Artinya keduanya saling membutuhkan guna tercapainya komunikasi yang efektif, masing-masing bekerja bersamasama untuk menciptakan suatu makna. Walaupun keduanya memiliki sifat holistic, namun keberadaannya menurut Don Stack dapat dibedakan menjadi tiga bagian:

\section{Kesengajaan (intentionality)}

Perbedaan utama antara komunikasi verbal dan non verbal adalah persepsi mengenai niat (intent).Michael Burgoon dan Michael Ruffner menegaskan bahwa pesan verbal adalah komunikasi jika dikirimkan dan diterima secara sengaja.

\section{Perbedaan-perbedaan simbolik (symbolic} differences)

Komunikasi verbal lebih spesifik dari bahasa noverbal, dalam arti, ia dapat dipakai untuk membedakan hal-hal yang sama dalam sebuah cara yang berubahubah. Sedangkan bahasa nonverbal lebih mengarah pada reaksi-reaksi alami seperti perasaan atau emosi.

\section{Mekanisme Pemrosesan (processing} mechanism)

Semua informasi termasuk komunikasi diproses melalui otak, kemudian otak menafsirkan informasi lewat pikiran yang berfungsi mengendalikan perilaku2 fisiologis (refleks) dan sosiologi (perilaku yang dipelajari dan perilaku sosial).Dalam bahasa Malandro dan Barker, ketidaksamaan tersebut, yaitu antara struktur dan nonstruktur, linguistic dan nonlinguistic, sinambung dan tidak sinambung, dipelajari dan diperoleh secara alamiah serta pemrosesan informasi otak sebelah kiri dan kanan (Effendy, 2005)

Keberadaan komunikasi verbal dan nonverbal dapat dipahami melalui funsgi-fungsi yang dilakukan keduanya.Fungsi dari lambanglambang verbal maupun noverbal adalah memproduksi makna yang komunikatif.

\section{Teori Struktur Kumulatif}

Dalam teori ini Ekman dan Friesen memfokuskan analisisnya pada makna yang diasosiasikan dengan kinesic yang disebut cumulative structure atau meaningcentered karena lebih banyak membahas makna yang berkaitan dengan gerak tubuh dan ekspresi wajah ketimbang struktur perilaku yang kemudian disebut sebagaiexpressive behaviour yang terdiri dari lima kategori:

a. Emblem: gerakan tubuh atau ekspresi wajah yang memiliki nilai samadengan pesan verbal, yang disengaja, dapat berdiri sendiri tanpa bantuan pesan verbal. Contoh: setuju, pujian, ucapan selamat jalan yang digantikan dengan anggukan kepala, acungan jempol dan lambaian tangan.

b. Ilustrator: gerakan tubuh/ekspresi wajah yang mendukung dan melengkapi pesan verbal. Contoh: raut muka serius ketika memberikan penjelasan utk menunjukkan bahwa yang dibicarakan adalah persolan serius, atau gerakan tangan yang menggambarkan sesuatu yang sedang dibicarakan.

c. Regulator: tindakan yang disengaja yang biasanya digunakan dalam percakapan, misalnya mengenai giliran berbicara. Contoh: senyuman,anggukan kepala, tangan yg menunjuk, mengangkat alis, orientasi tubuh. 
d. Adaptor: tindakan yang disengaja, yang digunakan untuk menyesuaikan tubuh dan menciptakan kenyamanan bagi tubuh dan emosi. Terdapat dua sub kategori adaptor, yaitu: Self (menggaruk kepala, menyentuh dagu/hidung) dan Object (menggigit pinsil, memainkan kunci). Perilaku ini biasanya dipandang sebagai refleksi kecemasan atau perilaku negative.

e. Emosi atau affect display: yang dapat disengaja atau tidak, dapat menyertai pesan verbal maupun berdiri sendiri yang bentuknya: marah, menghina, malu, takut, gembira, sedih dan terkejut.Affect display yang berbeda dapat diungkapkan secara bersamaan disebut Affect Blend.

\section{Teori Estetika}

Istilah estetika muncul pertama kali pada pertengahan abad ke-18, melalui seorang filsuf Jerman, Alexander Baumgarten, yakni estetika sebagai ranah pengetahuan sensoris, pengetahuan rasa yang berbeda dari pengetahuan logika, sebelum akhirnya ia sampai kepada penggunaan istilah tersebut dalam kaitan dengan persepsi atas rasa keindahan, khususnya keindahan karya seni.

Estetika berasal dari kata aistheton atau aisthetikos, Yunani Kuno, yang berarti persepsi atau kemampuan menyerap sesuatu secara inderawi. Emmanuel Kant melanjutkan penggunaan istilah tersebut dengan menerapkannya untuk menilai keindahan baik yang terdapat dalam karya seni maupun dalam alam.

\section{Ilmu Estetika Mengandung Dua Aspek:}

1. Aspek Ilmiah (scientific aspect); menggunakan cara-cara kerja (metodologi) yang sama dengan ilmu pengetahuan lain: observasi (pengamatan), analisa (pembahasan), eksperimen ( percobaan).

2. Aspek Filosofis (philosophical aspect); selain yang diatas, ditambah dengan komparasi (perbandingan), analogi (mengentarakan unsur persamaan), asosiasi (pengkaitan), sintesis (penggabungan), dan konklusi

(penyimpulan).

Penggunaan kata "estetika" berbeda dengan "filsafat" keindahan, karena estetika kini tidak lagi semata-mata menjadi permasalahan filsafat. Cakupan pembicaraan tentang keindahan dalam seni atau pengalaman estetis berkaitan juga dengan karya seni atau pengalaman estetis berkaitan juga dengan gaya atau aliran seni, perkembangan seni dan sebagaianya. (Ganda \& Perwira, 2004) Dalam hal ini seni yang dimaksud adalah film The Raid , kajian analisa estetikanya adalah rangkaian scene per scene yang mewarnai jalannya film The Raid hingga akhir melalui pengamatan tekhnik pengambilan gambar dan kualitas akting yang diperankan oleh tokoh dalam film The Raid.

Scene tersebut penulis dapat melihat dari tata cara penempatan sisi kamera terutama pada saat adegan aksi berlangsung.Estetika melihat bahwa keindahan dididapatkan melalui pengamatan yang berasal dari penginderaan.Dari film tersebut melihat unsur dari tata letak pengambilan gambar yang menjadi sebuah estetika dimana komposisi, angle, pergerakan kamera dan akting dari para tokoh.

\section{Teknik Pengambilan Gambar}

Ini adalah proses dimana gambar visual direkam dan dijadikan sebuah rangkaian cerita dengan tekhnik-tekhnik beragam seperti :

\section{a. Door Frame Shoot}

Teknik pengambilan gambar ini dilakukan dengan cara membuka sebuah pintu sedikit demi sedikit kemudian melongok ke bagian dalamnya. Seolah juru kamera mengintip tapi melalui pintu yang masih terbuka. Biasanya tekhnik seperti ini untuk memberikan kesan menegangkan dalam film-film horor,ketika suasana mencekam menghantui penonton mereka ingin tau apa sebetulnya yang terjadi dibalik pintu.

\section{b. Point of View Shoot (POV)}

Yakni memperlihatkan shot dalam posisi objek diagonsl dengan kamera. Ada dua jenis POV, yakni kamera sebagai 
subjek yang menjadi lawan objek. Sebagai subjek maka kamera membidik langsung kearah objek seolah subjek dan objek bertemu secara langsung, padahal tidak. Dalam teknik ini komposisi dan ukuran gambar harus diperhatikan.

\section{c. Artificial Framing Shoot}

Jika juru kamera menempatkan seutas daun pas didepan kamera maka hasil shot seolah juru kamera mengambil dari ranting pepohonan. Padahal dedaunan yang muncul sebetulnya hanya sengaja ditempatkan oleh juru kamera di depan lensa kamera.Efeknya, gambar dalam frame terasa lebih indah, terutama untuk shot kondisi dikebun atau hutan.

\section{d. Jaws Shot}

Biasanya objek akan tahu jika diambil gambarnya tapi dalam teknik ini justru seolah-olah objek tidak tahu, sehingga ketika kamera menyorot ke arahnya dia agak kaget, tapi tetap dalam situasi dramatik. Jaws yang berarti ikan hiu dipakai untuk menunjukkan keterkagetan objek manakala kamera membidik kearahnya.

\section{e. Overshoulder Shot}

Teknik pengambilan gambar melalui bahu pemain. Teknik ini mempunyai kesan menarik karena seolah mata lensa kamera mewakili pandangan seorang pemain (objek). Tentunya kaidah overshoulder shot ini juga disesuaikan dengan point of view shot. Artinya suatu objek melihat objek lainnya diwakili oleh kamera yang mengambil dengan cara over shoulder ini. Cukup baik digunakan untuk menggambarkan dua atau lebih objek yang saling berinteraksi secara simultan. Sementara ukuran bahunya tentu disesuaikan dengan kepentingan shot yang bersangkutan. Tidak terlalu banyak dan tidak terlalu sedikit,normal saja.

\section{f. Walking Shot}

Sesuai dengan namanya teknik ini megambil ini mengambil gambar pada objek yang sedang berjalan. Kesannya indah karena memperlihatkan seseorang yang sedang berjalan ternuru-buru. Biasanya digunakan untuk film-film laga yang memperlihatkan tokokh antagonis sedang mengejar tokoh protagonis.Dengan teknik ini seolah penonton menjadi objek yang berlari mengejar atu dikejar sesuai denga konteks isi film.

\section{Camera Angle}

Kamera angle adalah aspek pengambilan sudut gambar dalam produksi sebuah karya visual. Dimana posisi kamera pada saat anda membidik suatu objek akan berpengaruh pada makna dan pesan yang akan disampaikan. Sudutu pengambilan high angle (dari atas objek) sangat berbeda maknanya dengan low angle (dari bawah objek). Prinsipnya dalam urusan teknik pengambilan gambar dapat dibagi menjadi empat kategori, yaitu sudut pengambilan gambar, ukuran shot, gerakan objek dan gerakan kamera.

\section{a. Bird Eye View}

Adalah suatu teknik pengambilan gambar yang dilakukan juru kamera dengan posisi kamera berada diatas ketinggian objek yang direkam. Hasil perekaman teknik ini memperlihatkan lingkungan yang demikian luas dengan benda-benda lain yang tampak dibawah begitu kecil dan berserakan tanpa punya makna. Sudut pengambilan gambar ini misalnya dilakukan dari helikopter atau dari gedung bertingkat tinggi.

Tujuan dari sudut pengambilan gambar ini untuk memperlihatkan objek-objek yang lemah ,sesuatu erkucil dan perlu bantuyang kurang bermakna dengan maksud menghinakan. Untuk juru kamera berita biasanya untuk suatu daerah yang mengenaskan. Objek begitu merana, terkucil dan perlu bantuan. Dengan gambaran bird eye view penonton akan merasa iba, tergerak hatinya untuk ikut merasakan penderitaan objek.

\section{b. High Angle}

Sudut pengambilan gambar ini lebih rendah dari bird eye view. High angle merupakan pengambilan 
gambar dari atas objek. Selama kamera berada diatas objek makan akan disebut high angle,dengan teknik ini maka objek akan terlihat kecil. Disini bukan soal tampilan fisiknya, yang penting adalah kesan yang ditimbulkan dari pengambilan gambar ini adalah kesan "lemah"," tak berdaya ", " kesendirian " dan kesan lain yang mengandung arti " dilemahkan " atau " dikerdilkan ".

\section{c. Eye Level}

Jika kamera berdiri sejajar dengan objek itulah yg dinamakan eye level. Posisi kamera dan objek sejajar sehingga gambar yang didaptkan tidak keatas atau kebawah. Sudut pengambilan gambar ini amat lazim dilakukan oleh juru kamera. Hasilnya memperlihatkan tangkapan pandangan mata seseorang yang berdiri atau pandangan mata seseorang yang mempunyai ketinggian tubuh tepat tingginya sama dengan objek.

\section{d. Frog Eye}

\section{Merupakan}

teknik

pengambilan gambar yang dilakukan oleh juru kamera dengan ketinggian kamera sejajar dengan dasar (alas) kedudukan objek. Dengan teknik ini dihasilkan satu pemandangan objek yang besar, terkadang mengerikan bisa juga penuh misteri. Pastinya sudut pengambilan gambar ini mempunyai kesan yang dramatis untuk memperlihatkan suatu pemandangan yang aneh, ganjil, “ kebesaran ", atau " sesuatu " yang menarik tapi diambil dengan variasi tidak biasanya.

\section{Shot}

Shot adalah ketika seseorang melakukan on sampai off pada suatu adegan. Shot diartikan sebagai unsur terkecil dari sebuah struktur film yang utuh, didalamnya kita bisa melihat isi pesan dari shot itu sendiri.

Ada beberapa batasan hal yang terkandung dalam sebuah shot :

\section{Faktor Manusia}

Dalam sebuah shot, tentu ada unsur ini karena merupakan bagian integral dengan peristiwa yang ingin disajikan dalam film. Adanya subjek manusia atau subjek lainnya dihadirkan untuk melambangkan perwatakkan ataupun masalah utama dalam sebuah film.

\section{Faktor Ruang}

Faktor ruang ini terbagi menjadi dua, ruangan alami dan non alami. Ruangan alami adalah ruang atau tempat yang sesungguhnya untuk sebuah peristiwa terjadi sedangkan ruang non alami adalah ruang atau tempat pengganti yang dipakai sebagai terjadinya suatu peristiwa. Dengan kata lain ruang non alami adalah studio yang biasa dipakai untuk rekayasa tempat sesuai dengan kebutuhannya. Pada produksi film non fiksi unsur ruang menjadi unsur yang sangat penting karena faktor ini kita bisa melihat faktor kandungan yang menjadi sebuah informasi dari zaman, status sosial dan situasi tentang peristiwa terjadi.

\section{Faktor Waktu}

Faktor ini dalam film bisa memiliki dua pengertian, yaitu pengertian waktu secara fisik seperti siang, pagi, malam dan sore serta waktu kejadian ketika sebuah peristiwa sedang berlangsung. Disamping itu, faktor waktu dalam media film (film time) bisa berbeda dengan waktu kejadian sesungguhnya (real time) ketika sebuah peristiwa terjadi.

\section{Faktor Peristiwa Dramatik}

Tanpa adanya peristiwa, ruang dan waktu tidak akan memiliki nilai dramatik. Peristiwa dalam film realitasnya sangat relatif, sementara peristiwa dalam film bisa dimungkinkan untuk menimbulkan reaksi emosional penonton yang lebih besar, dibandingkan dengan peristiwa realitasnya sendiri. Pada film-film dokumenter, peristiwa yang sifatnya faktual dan aktual menuntut editor untuk lebih jeli melihat jalinan materi shot yang tersedia karena sering peristiwa yang terjadi baru bisa dipahami setelah beberapa shot dirangkai. 


\section{Faktor Suara}

Faktor suara adalah salah satu kelebihan media film yang juga memiliki kemampuan untuk diolah secara kreatif, sama seperti unsur gambarnya. Faktor suara bisa berfungsi sebagai informasi ruang, waktu dan peristiwa, yang pada awalnya ketika suara bisa masuk kedalam film hanya berfungsi sebagai pelengkap dan penunjang gambar. Bahkan para pembuat film saat ini, memasukkan musik film pun sering mempertimbangkan tahun produksi itu sendiri, baik sebagai usaha untuk mencapai tahun aktualitas film itu terjadi maupun hanya mengembalikan memori penonton, pada tahun tentang musik itu di produksi (Syahid, 2000, 34).

\section{Visual Efek dan Spesial Efek}

Visual Effect (Visual F/X; Vfx). Serangkaian proses pembuatan gambar yang menyertakan proses manipulasi tertentu di luar adegan pengambilan gambar syuting asli. Efek visual merupakan perpaduan dari gambar syuting asli dengan objek rekayasa komputer, serta objek lainnya untuk menciptakan adegan yang realistis sesuai dengan tuntutan skenario. Hal ini dilakukan misalnya karena adegan tersebut berbahaya untuk dilakukan oleh para pemeran, atau berbiaya tinggi, atau bahkan mustahil untuk divisualkan secara nyata.

Efek visual pada film era modern dapat ditemukan pada film King Kong (Merian C. Cooper dan Ernest B. Schoedsack, 1933). Kera besar itu, sebenarnya, hanya boneka berukuran 18 inci dengan tungkai dan lengan yang dapat digerakkan. King Kong adalah film pertama yang menggunakan teknik front projectionmenempatkan aktor di depan gambar sehingga terlihat bahwa aktor adalah bagian dari gambar. Pada era selanjutnya, komputer mengambil alih pembuatan visual efek. Star Wars menggunakan kamera yang dikendalikan komputer untuk mengonstruksi gambar pertempuran multilayered.

Spesial efek dalam bahasa Indonesai sering disingkat SFX banyak digunakan dalam dunia perfilman, pertelevisian dan hiburan. Dengan definisi ini, efek spesial tidak Cuma terdapat dalam film, seperti yang diketahui masyarakat awam. Efek spesial tidak hanya berwujud gambar, tetapi memiliki perngertian luas. Apapun bentuknya, efek spesial digunakan untuk meningkatkan dampak suatu objek terhadap indera manusia.

Objek tersebut bisa berupa tontonan, gambar, atau pertunjukkan. Dengan demikian diharapkan efek spesial bisa meningkatkan ketertarikan seseorang terhadap objek tersebut. Egek spesial merupakan kombinasi dari seni dan teknologi. Dari sisi teknologi, tidak Cuma penguasaan teknologi yang digunakan, namun juga pengetahuan bagaimana indera manusia menangkap gambaran yang akan diterima oleh otak. Sedangkan sisi seni, berperan tentang bagaimana teknologi tersebut digunakan untuk mencapai hal tersebut.

\section{METODOLOGI PENELITIAN}

Dalam penelitian ini, penulis menggunakan analisis kualitatif deskriptif. Kualitatif bermaksud untuk memahami fenomena tentang sesuatu oleh subjek penelitian (misalnya perilaku, persepsi, motivasi, tindakan dan lain-lain) secara holistic (utuh) dengan cara mendeskripsikan dalam bentuk kata-kata dan bahasa, pada suatu konteks khusus yang alamiah dengan memanfaatkan berbagai metode alamiah. (Moleong, 2005)

Sifat-sifat penelitian deskriptif menurut (Surakhmad, 1990) adalah sebagai berikut :

1. Memusatkan diri pada pemecahan masalah yang ada pada masa sekarang pada masalah-masalah yang aktual.

2. Data yang dikumpulkan mula-mula disusun, dijelaskan, kemudian dianalisa; karena itu penelitian ini sering juga disebut dengan penelitian analitik.

3. Menjelaskan setiap langkah penyelidikan deskriptif itu dengan teliti dan terperinci, baik mengenai dasar-dasar metodelogi maupun mengenai data teknis secara langsung.

4. Menjelaskan prosedur pengumpulan data, serta pengawasan dan penilaian terhadap data itu.

5. Memberi alasan yang kuat mengapa dalam metode deskriptif tersebut penyidik menggunakan teknik tertentu dan bukan teknik lainnya.

\section{HASIL DAN PEMBAHASAN}

Dalam pengamatan ini penulis melihat nilai-nilai estetika yang penulis analisa melalui tekhnik pengambilan gambar, akting para tokoh, dan efek dramatisir. 


\section{Teknik Pengambilan Gambar a. Door Frame Shoot}

Teknik pengambilan gambar ini dilakukan dengan cara membuka sebuah pintu sedikit demi sedikit kemudian melongok ke bagian dalamnya. Seolah juru kamera mengintip tapi melalui pintu yang masih terbuka. Biasanya tekhnik seperti ini untuk memberikan kesan menegangkan dalam film-film horor,ketika suasana mencekam menghantui penonton mereka ingin tau apa sebetulnya yang terjadi dibalik pintu.

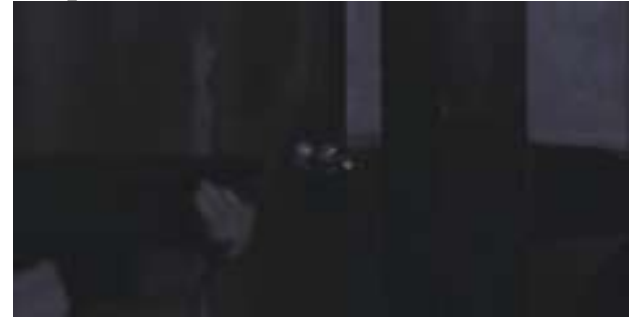

Gambar 4.1

Dimana salah seorang penyerbu dari satuan khusus membuka dengan hati-hati pintu yang di dalamnya belum terindentifikasi kondisinya.

\section{b. Point of View Shoot (POV)}

Yakni memperlihatkan shot dalam posisi objek diagonal dengan kamera. Ada dua jenis POV, yakni kamera sebagai subjek yang menjadi lawan objek. Sebagai subjek maka kamera membidik langsung kearah objek seolah subjek dan objek bertemu secara langsung, padahal tidak. Dalam teknik ini komposisi dan ukuran gambar harus diperhatikan.

Jenis POV yang kedua adalah kamera sebagai orang ketiga. Maka tugas kamera seperti layaknya pendengar dalam sebuah obrolan. Seorang pendengar dia akan selalu memperhatikan orang yang sedang berbicara.

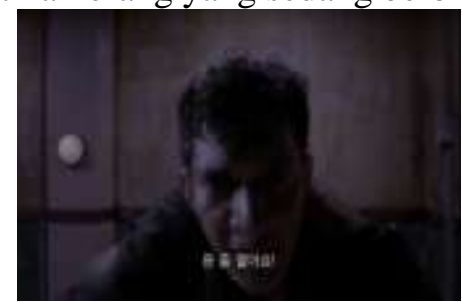

Gambar 4.2

Dimana aktor utama berteriak kepada kamera,seolah kamera merupakan orang yang dimaksud (pihak ketiga).

Pada adegan ini terdapat nilai estetika berdasarkan teknik pengambilan gambar Points of View karena menunjukkan sisi dari akting tokoh utama yang seadng kalap mencari bantuan karena dirinya beserta temannya yang terluka tengah terancam.

Shoot

Jika juru kamera menempatkan seutas daun pas didepan kamera maka hasil shot seolah juru kamera mengambil dari ranting pepohonan. Padahal dedaunan yang muncul sebetulnya hanya sengaja ditempatkan oleh juru kamera di depan lensa kamera.Efeknya, gambar dalam frame terasa lebih indah, terutama untuk shot kondisi dikebun atau hutan.

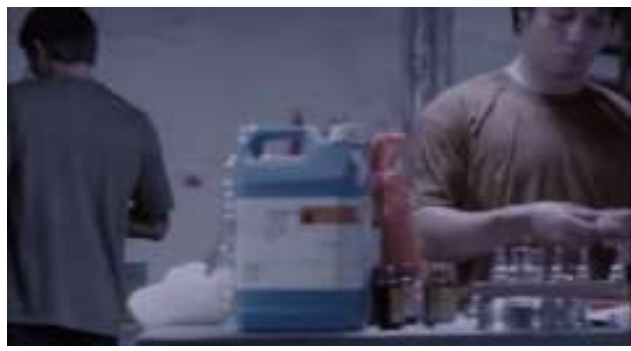

Gambar 4.3

Suasana pembuatan narkotika di dalam markas yang sedang diserbu.

Pada pengambilan gambar kali ini menggunakan teknik Artificial Shot atau yang lebih dikenal dengan nama Fore Ground yaitu pada film The Raid memperlihatkan deretan bahan pembuat narkoba seolah menghalangi sosok dari si pembuat narkoba. Estetikanya adalah dengan adanya deretan bahan tersebut memperjelas kegiatan apa yang sedang dilakukan pada adegan tersebut.

\section{d. Jaws Shot}

Biasanya objek akan tahu jika diambil gambarnya tapi dalam teknik ini justru seolaholah objek tidak tahu, sehingga ketika kamera menyorot ke arahnya dia agak kaget, tapi tetap dalam situasi dramatik. Jaws yang berarti ikan hiu dipakai untuk menunjukkan keterkagetan objek manakala kamera membidik kearahnya.

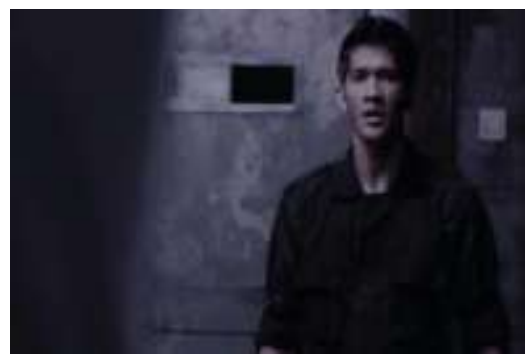

Gambar 4.4 
Dimana tokoh utama merasa terkejut ketika kamera membidik kearahnya karena kedatangannya diketahui oleh musuh yang sedang mencarinya.

\section{e. Overshoulder Shot}

Teknik pengambilan gambar melalui bahu pemain. Teknik ini mempunyai kesan menarik karena seolah mata lensa kamera mewakili pandangan seorang pemain (objek).

Tentunya kaidah overshoulder shot ini juga disesuaikan dengan point of view shot. Artinya suatu objek melihat objek lainnya diwakili oleh kamera yang mengambil dengan cara over shoulder ini. Cukup baik digunakan untuk menggambarkan dua atau lebih objek yang saling berinteraksi secara simultan. Sementara ukuran bahunya tentu disesuaikan dengan kepentingan shot yang bersangkutan. Tidak terlalu banyak dan tidak terlalu sedikit,normal saja.

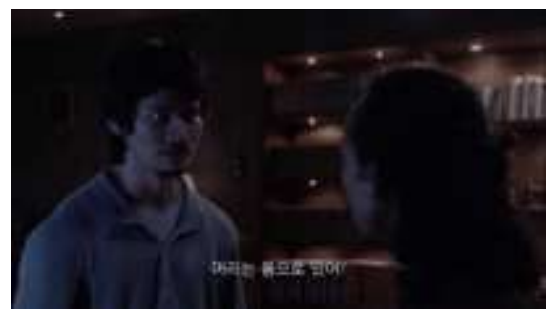

Gambar 4.5

Dimana pada shot kali ini salah satu aktor yaitu

Dony Alamsyah sedang berdialog dengan

Yayan yang adalah temannya .

Pada adegan kali ini estetika terdapat pada teknik pengambilan dimana lawan bicara mendapat efek blur (tidak jelas) dengan tujuan memperjelas siapa yang sedang berbicara dan makna yang sedang dibicarakan. Pada teknik kali ini amat sangat memperhatikan apa namanya garis imajiner.

\section{f. Walking Shot}

Sesuai dengan namanya teknik ini megambil ini mengambil gambar pada objek yang sedang berjalan. Kesannya indah karena memperlihatkan seseorang yang sedang berjalan ternuru-buru. Biasanya digunakan untuk film-film laga yang memperlihatkan tokokh antagonis sedang mengejar tokoh protagonis.Dengan teknik ini seolah penonton menjadi objek yang berlari mengejar atu dikejar sesuai denga konteks isi film.

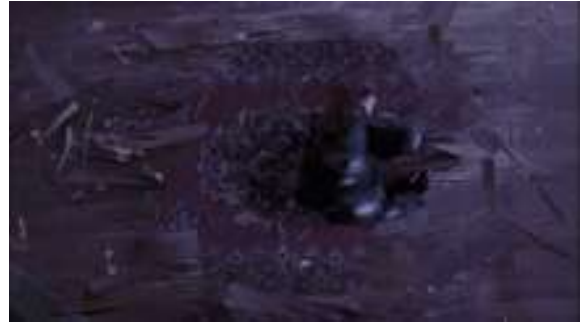

Gambar 4.6

Dimana adegan kali ini beberapa anggota satuan khusus melompat kebawah melewati lubang lantai yang bolong.

Teknik pengambilan gambar seperti ini merupakan sebuah tantangan bagi seorang juru kamera karena membutuhkan kemampuan yang amat sangat mumpuni dalam mengendalikan kamera. Mengingat lokasi yang tidak lazim yaitu kamera ikut melompat melewati lubang lantai seolah kamera adalah objek. Estetika pada shot ini sangat jelas yaitu mata penonton diwakili oleh kamera yang melakukan pergerakan tadi.

\section{Camera Angle}

\section{a. High Angle}

Sudut pengambilan gambar ini lebih rendah dari bird eye view. High angle merupakan pengambilan gambar dari atas objek. Selama kamera berada diatas objek makan akan disebut high angle,dengan teknik ini maka objek akan terlihat kecil. Disini bukan soal tampilan fisiknya, yang penting adalah kesan yang ditimbulkan dari pengambilan gambar ini adalah kesan "lemah"," tak berdaya ", " kesendirian " dan kesan lain yang mengandung arti " dilemahkan " atau " dikerdilkan “.

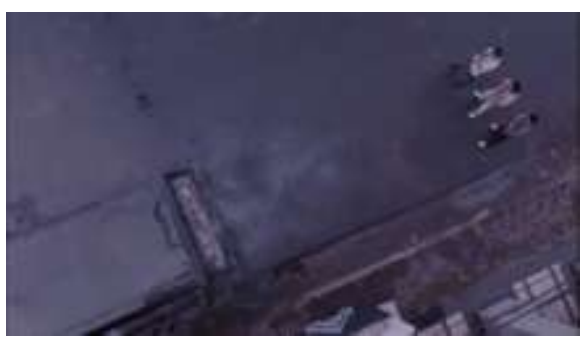

Gambar 4.9

Dimana adegan ini terdapat visual mobil anggota satuan khususyang berisi supir ditembaki oleh gerombolan bandar narkoba. 
Hampir sama dengan angle bird eye view namun bedanya pada high angle kamera lebih jelas berada diatas objek dan penglihatan penonton pun bisa lebih jelas melihat apa yang sedang terjadi. Ini merupakan estetika yang terdapat pada angle ini, efek yang didapatkan pun menjadi lebih dramatisir terhadap penonton. Untuk adegan ini tidak bisa manggambarkan kewibawaan manusia karena kesan yang ditimbulkan akan melenceng.

\section{b. Eye Level}

Jika kamera berdiri sejajar dengan objek itulah yg dinamakan eye level. Posisi kamera dan objek sejajar sehingga gambar yang didaptkan tidak keatas atau kebawah. Sudut pengambilan gambar ini amat lazim dilakukan oleh juru kamera. Hasilnya memperlihatkan tangkapan pandangan mata seseorang yang berdiri atau pandangan mata seseorang yang mempunyai ketinggian tubuh tepat tingginya sama dengan objek.

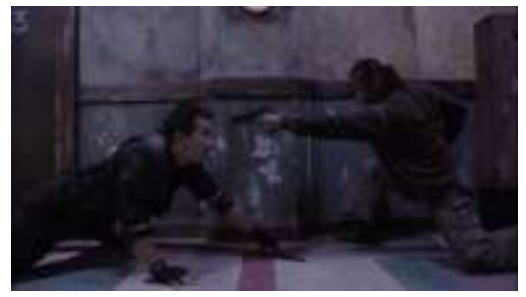

Gambar 4.0

Dimana pada adegan ini ada dua tokoh yang sedang berhadapan. Sudut pandang kamera sejajar dengan mata keduanya.

Pada adegan tersebut letak kamera sejajar dengan posisi objek dimana kamera dengan mata sejajar garis lurus. Estetika yang terdapat yaitu adanya kesan yang natural, alami, tidak direkayasa terhadap objek dan gambar yang ditangkap oleh kamera. Penginderaan oleh penonton menghasilkan efek yang tidak dibuatbuat tetapi penonton seolah mendapatkan keadaan yang real berdasarkan pengamatan.

\section{c. Frog Eye}

Merupakan teknik pengambilan gambar yang dilakukan oleh juru kamera dengan ketinggian kamera sejajar dengan dasar (alas) kedudukan objek. Dengan teknik ini dihasilkan satu pemandangan objek yang besar, terkadang mengerikan bisa juga penuh misteri. Pastinya sudut pengambilan gambar ini mempunyai kesan yang dramatis untuk memperlihatkan suatu pemandangan yang aneh, ganjil, “ kebesaran ", atau " sesuatu " yang menarik tapi diambil dengan variasi tidak biasanya.

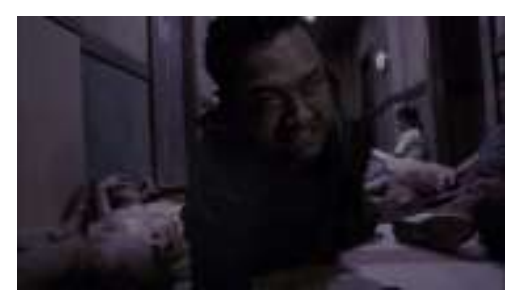

Gambar 4.11

Dimana ada sebuah adegan yang memperlihatkan salah satu anggota satuan

khusus sedang merangkak kesakitan.

Pada adegan ini terlihat seorang anggota satuan khusus yang merangkak kesakitan karena terluka. Angle yang digunakan adalah frog eye karena nilai estetika yang terkandung yaitu menhasilkan efek yang didapat. Penonton mendapatkan kesan yang natural tanpa adanya rekayasa dalam visual ini, karena posisi objek yang rendah namun sejajar oleh letak kamera.

\section{Visual Efek}

Spesial efek dalam bahasa Indonesai sering disingkat SFX banyak digunakan dalam dunia perfilman, pertelevisian dan hiburan. Dengan definisi ini, efek spesial tidak Cuma terdapat dalam film, seperti yang diketahui masyarakat awam. Efek spesial tidak hanya berwujud gambar, tetapi memiliki perngertian luas. Apapun bentuknya, efek spesial digunakan untuk meningkatkan dampak suatu objek terhadap indera manusia.

Objek tersebut bisa berupa tontonan, gambar, atau pertunjukkan. Dengan demikian diharapkan efek spesial bisa meningkatkan ketertarikan seseorang terhadap objek tersebut. Egek spesial merupakan kombinasi dari seni dan teknologi. Dari sisi teknologi, tidak Cuma penguasaan teknologi yang digunakan, namun juga pengetahuan bagaimana indera manusia menangkap gambaran yang akan diterima oleh otak. Sedangkan sisi seni, berperan tentang bagaimana teknologi tersebut digunakan untuk mencapai hal tersebut. 


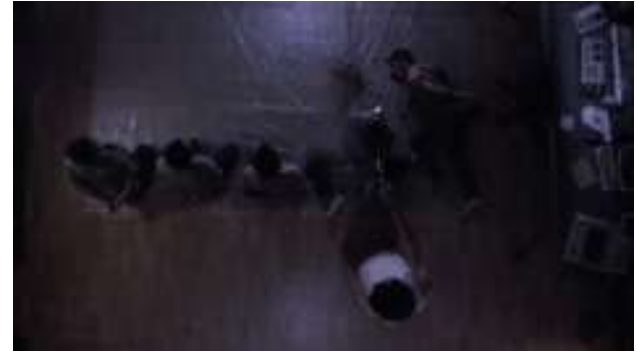

Gambar 4.12

Dimana pada adegan ini salah satu tokoh menembak kepala para korban.

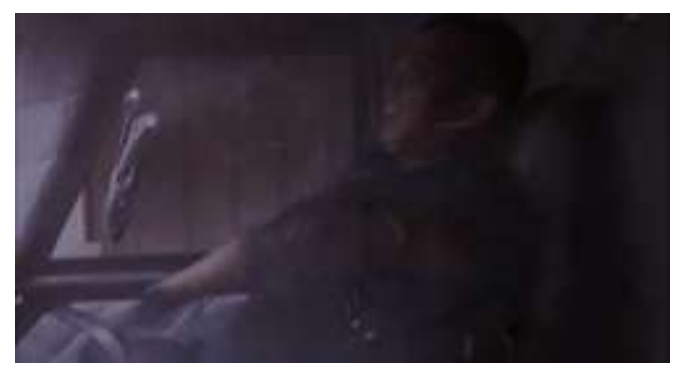

Gambar 4.13

Dimana supir dari satuan khusus ditembaki oleh para gembong narkoba dari jarak kurang lebih 7 meter.

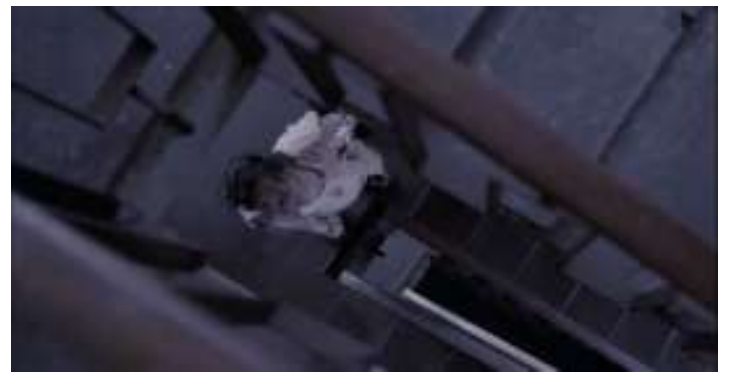

Gambar 4.14 : Adegan ini memperlihatkan ditembaknya ketua gembong dari jarak dekat pada kepala oleh salah satu anggota satuan khusus

Pada keseluruhan teknik visual efek yang ada pada film The Raid menambah kesan nyata untuk kejadian yang seharusnya membutuhkan sentuhan kreatif seperti contohnya darah yang keluar akibat dari tembakan, bacokan dan adegan-adegan aksi lainnya. Terdapat nilai estetika dari adanya teknik spesial efek ini karena penginderaan penonton mengakibatkan aanya pengamatan yang menghasilkan pesan berupa kesan alami terhadap film tersebut.

\section{Gestur dan Komunikasi}

Walaupun masyarakat berbeda-beda, banyak tipe gestur yang sama yang dipergunakan untuk meningkatkan atau menggantikan komunikasi verbal. Ada gestur gestur yang memberikan arti konsisten dalam situasi-situasi yang serupa. Dengan demikian berfungsi sebagai satu sistem simbolis, yang istilahnya lebih dikenal dengan nama bahasa tubuh. Karena fungsi aimbolis ini, gestur memberikan analogi yang terbentuk fisik unutk aksi-aksi atau perasaan-perasaan yang sedang diekspresikan atau digambarkan.Ketika bahasa verbal memberikan sistem komunikasi yang artinya sudah cukup jelas dan tepat, bahasa tubuh memberikan informasi tentang perasaanperasaan dan aksi-aksi dengan lebih ekspresif daripada kata-kata.

Dalam buku Literature as Experience dikatakan :

Gestur mencapai nilai analogis tertinggi ketika mengekspresikan emosi, tetapi gestur terus berfungsi sebagai pernyataan-pernyataan ditempat umum, di permainan-permainan dan bahkan dalam percintaan.Segi komunikatif yang diciptakan gestur dapat beragam dari yang paling universal sampai yang paling aneh, bahkan bodoh.Gestur dapat menggantikan kata-kata atau mendukung kata-kata.

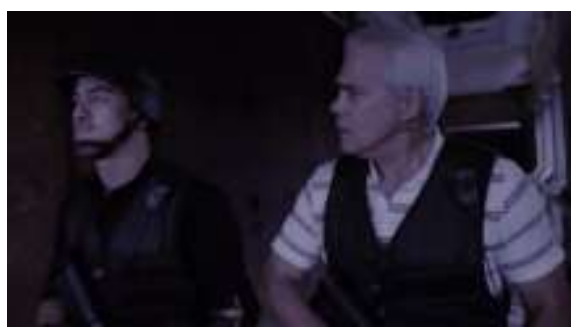

Gambar 4.15

Pierre Gruno dan Joe Taslim sedang berjalan dan bercakap-cakap sesaat sebelum penyerbuan ke markas gembong narkoba.

Pada konteks adegan ini terdapat sisi estetika dari fungsi gestur dan komunikasi dimana keduanya dapat memerankan dari masing-masing karakter.Keduanya seolah menjadi benar-benar anggota satuan khusus dalam misi menyerbu ke dalam markas anggota narkoba. Joe Taslim berperan sebagai 
komandan yang berwibawa dan Pierre Gruno menjadi salah satu anggota bantuan dari pihak aparat lain yang ternyata mempunyai misi khusus tanpa diketahui oleh Joe Taslim sebagai komandan penyerbuan.

\section{Aktor dan Suaranya}

Kita menggunakan cara-cara yang nonlinguistik ini untuk mengekspresikan ideide, sebagai pendukung berbicara.Tangisan infleksi nada, gestur adalah cara-cara berkomunikasi yang lebih universal untuk disampaikan ke binatang. (Sitorus, 2002)

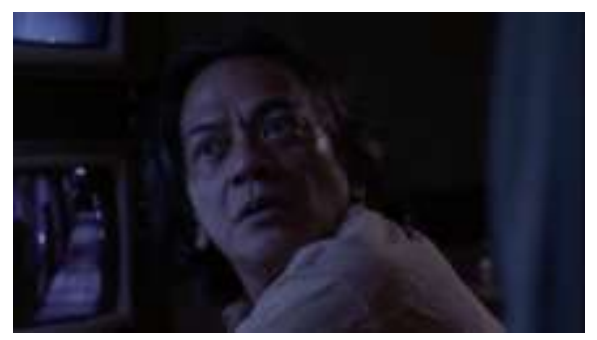

Gambar 4.16

Ray Sahetapy sedang menerima laporan tentang kedatangan anggota satuan khusus yang tengah menyerbu markasnya.

Ray Sahetapy berperan sebagai pimpinan dari gembong narkoba ini. Karakternya adalah bersifat keras, sadis dan juga tidak mengenal kompromi. Bahkan dia pun selalu berbicara dalam nada keras seolah selalu dalam keadaan marah. Dia memerankan tokoh ini dengan sangat sempurna sehingga pengamatan penonton terbawa oleh perannya yang menjiwai dan menjadikan sebuah nilai estetika dari segi akting dan suara.

\section{KESIMPULAN}

Sebuah produksi film di tanah air dapat berkembang bila ada sesuatu yang di dukung dengan pengambilan gambar dan teknik yang baik dalam sebuah produksi itu sendiri . Dalam sebuah karya film yang merupakan gabungan antara sisi audio dan sisi visual pastinya terdapat nila-nilai estetika yang menjadi ciri atau selera dari film tersebut. Sama halnya dengan film layar lebar Indonesia The Raid, dimana nilai-nilai estetika didapatkan dari unsur teknik pengemasan gambar, seni peran dan akting juga spesial efek .

\section{REFERENSI}

Effendy, P. D. O. U. (2005). Ilmu Komunikasi : Teori Dan praktek. PT Remaja Rosdakarya.

Ganda, D. S. \& K. N., \& Perwira. (2004). Memahami Seni dan Estetika. Bandung: Rekayasa Sains.

Moleong, L. J. (2005). Metodologi Penelitian Kualitatif (1st ed.). Bandung: Remaja Rosdakarya.

Sitorus, E. D. (2002). The Art Of Acting. indonesia: Gramedia Pustaka Utama.

Sumardjo, J. (2000). Filsafat Seni. Bandung: ITB.

Surakhmad, P. D. W. (1990). Pengantar Penelitian Ilmiah Dasar Metode Teknik. Tarsito.

Susanto, D. P. A. S. (1982). Komunikasi massa. Bina Cipta.

\section{PROFIL PENULIS}

Tentang Penulis : Muhammad Ichsan kelahiran Depok, 07 Oktober 1989 bekerja dibidang pendidikan Univeritas Bina Sarana Informatika bidang penyiaran sebagai pengajar dimulai tahun 2012 hingga sekarang. 